\title{
Expansion of subarctic water masses in the North Atlantic and Pacific oceans and implications for mid-Pleistocene ice sheet growth
}

\author{
Erin L. McClymont, ${ }^{1,2}$ Antoni Rosell-Melé, ${ }^{3,4}$ Gerald H. Haug, ${ }^{5}$ and Jerry M. Lloyd ${ }^{1}$ \\ Received 11 March 2008; revised 9 September 2008; accepted 13 October 2008; published 17 December 2008.
}

[1] Past surface ocean circulation changes associated with the mid-Pleistocene transition, 0.9-0.6 Ma, were reconstructed in the northern North Atlantic (ODP 983) and the northwest Pacific (ODP 882), using proxies for subarctic/subpolar water mass distributions $\left(\% \mathrm{C}_{37: 4}\right.$ alkenone) and sea surface temperature $\left(\mathrm{U}_{37}^{\mathrm{K}}\right)$. Both sites experienced a secular expansion of subarctic waters from $\sim 1.15 \mathrm{Ma}$, spanning both glacial and interglacial intervals. After $0.9 \mathrm{Ma}$, low $\% \mathrm{C}_{37: 4}$ at Site 983 records a northward retreat of subarctic waters during interglacials in the Atlantic, while continued high glacial $\% \mathrm{C}_{37: 4}$ indicate extensive subarctic waters during glacial maxima associated with the development of the larger late Pleistocene ice sheets. In contrast, a secular decline in $\% \mathrm{C}_{37: 4}$ occurred at Site 882 from 0.9 to $0.5 \mathrm{Ma}$, marking a more gradual retreat of subarctic conditions in the Pacific. It is proposed that the expansion of subarctic waters between 1.15 and 0.9 Ma exerted negative feedbacks to the moisture supply to the ice sheet source regions and may account for the apparent delayed ice sheet response to atmosphere-ocean circulation changes associated with the mid-Pleistocene transition that began as early as 1.2 Ma.

Citation: McClymont, E. L., A. Rosell-Melé, G. H. Haug, and J. M. Lloyd (2008), Expansion of subarctic water masses in the North Atlantic and Pacific oceans and implications for mid-Pleistocene ice sheet growth, Paleoceanography, 23, PA4214, doi:10.1029/2008PA001622.

\section{Introduction}

[2] The early to middle Pleistocene was marked by a series of climatic, environmental and faunal changes that resulted in a major transition for the global climate system and the evolution of many modern biotic assemblages [Head and Gibbard, 2005]. A shift toward a cooler climate, and the development of larger Northern Hemisphere ice sheets at $\sim 0.9 \mathrm{Ma}$, was accompanied by an increase in the duration and intensity of the glacial cycles from $41 \mathrm{ka}$ to 100 ka by $0.6 \mathrm{Ma}$ : the "mid-Pleistocene climate transition" or MPT [Imbrie et al., 1993; Mudelsee and Schulz, 1997]. In the tropics and subtropics, the MPT was marked by intensification of the Trade winds [Durham et al., 2001; Liu and Herbert, 2004; Marlow et al., 2000], Walker circulation [McClymont and Rosell-Melé, 2005; Medina-Elizalde and Lea, 2005], Asian monsoon [Heslop et al., 2002; Xiao and $A n, 1999]$, and increasing continental aridity [de Menocal, 1995; Schefuß et al., 2003]. The high latitudes also underwent transformations during the MPT, as indicated by changes in ice sheet size [Clark and Pollard, 1998], the thermohaline circulation [Oppo et al., 1995; Raymo et al.,

\footnotetext{
${ }^{1}$ Department of Geography, University of Durham, Durham, UK.

${ }^{2}$ Now at School of Geography, Politics, and Sociology, Newcastle University, Newcastle upon Tyne, UK.

${ }^{3}$ Institució Catalana de Recerca i Estudis Avançats, Barcelona, Catalonia, Spain.

${ }^{4}$ Institut de Ciència i Tecnologia Ambientals, Universitat Autònoma de Barcelona, Bellaterra, Catalonia, Spain.

${ }^{5}$ Geological Institute, Department of Earth Sciences, ETH Zürich, Zürich, Switzerland.
}

Copyright 2008 by the American Geophysical Union. 0883-8305/08/2008PA001622
1990; Schmieder et al., 2000], and variations to the position of the frontal systems associated with the Antarctic Circumpolar Current [Becquey and Gersonde, 2002; Diekmann and Kuhn, 2002; McClymont et al., 2005]. The early and middle Pleistocene is also a key interval for biotic change, with faunal turnovers, extinctions and migrations found in both marine and terrestrial archives [e.g., Azzaroli, 1995; de Menocal, 2004; Head and Gibbard, 2005; Kawagata et al., 2005; O'Neill et al., 2007; Opdyke, 1995; Sikes, 1999], that may be linked to the climate events of the MPT.

[3] The drivers of the MPT are still undetermined. The transition has been attributed to an apparent change in the sensitivity of global climate to eccentricity forcing and/or the development of an internal regulatory mechanism at the $100 \mathrm{ka}$ frequency. The greater inertia of larger Northern Hemisphere ice sheets after 0.9 Ma has been proposed to account for the longer and asymmetric glacial-interglacial (G-IG) cycles [e.g., Berger and Jansen, 1994; Clark and Pollard, 1998; Imbrie et al., 1993; Mudelsee and Schulz, 1997]. However, before any apparent variation in the volume of the Northern Hemisphere ice sheets, a shift from 41 ka to 100 ka periodicity was apparent in the variability of some climate system components. For instance, an "early" emergence of the $100 \mathrm{ka}$ period has been identified in a planktonic $\delta^{18} \mathrm{O}$ record from the West Pacific Warm Pool from 1.2 Ma [Berger et al., 1993]. This occurred at the same time that a "premature" $100 \mathrm{ka}$ cycle in benthic $\delta^{18} \mathrm{O}$ and thermohaline circulation strength was recorded in the South Atlantic [Schmieder et al., 2000].

[4] Ice sheet growth depends upon factors that determine the balance between accumulation and ablation. Although temperature is an important influence, there must also be 
sufficient precipitation to create a positive mass balance in the ice sheet source regions. The North Atlantic and Pacific Oceans are important sources of heat and water vapor transport to Europe and boreal America, i.e., to the Northern Hemisphere ice sheet source regions [Koster et al., 1986]. On the basis of the modeling results, it has been proposed that more extensive sea ice cover during the mid-Pleistocene could account for the regulation and emergence of the 100 ka cycles, described as a "sea ice switch" mechanism [Gildor and Tziperman, 2001; Tziperman and Gildor, 2003]. In fact, relatively restricted Atlantic sea ice cover may have been important for maintaining moisture supplies to the Northern Hemisphere ice sheets during glacial inceptions [e.g., McManus et al., 2002; Ruddiman and McIntyre, 1979; Ruddiman et al., 1980], and the persistence of warmer surface waters into autumn in the North Pacific as a result of increased stratification has been linked to the intensification of Northern Hemisphere glaciation at 2.7 Ma [Haug et al., 2005].

[5] Here, we investigate surface ocean circulation in the northern Atlantic and Pacific Oceans across the MPT. We present results from two Ocean Drilling Program (ODP) sites covering the time interval $1.5-0.5 \mathrm{Ma}$ (Figure 1): North Atlantic Site 983 and northwest Pacific Site 882. Although the Arctic Front that divides Atlantic and Arctic waters presently lies to the north of Site 983, it is known to have migrated southward during glacials of the Pleistocene bringing much cooler waters and potentially also sea ice to the site [e.g., Bard et al., 1987; Rosell-Melé et al., 1998; Wright and Flower, 2002]. In contrast, sea ice does not appear to have reached Site 882 over the Pliocene and Pleistocene; rather, glacials are associated with increasing polar stratification [Haug et al., 2005, 1999; Jaccard et al., 2005]. We monitor the extent of cool and fresh arctic and polar waters using the concentration of the tetra-unsaturated alkenone, $\mathrm{C}_{37: 4}$ [Bendle and Rosell-Melé, 2004; Bendle et al., 2005; Rosell-Melé, 1998; Rosell-Melé et al., 1994]. Sea surface temperatures (SSTs) are reconstructed using the alkenone-derived $\mathrm{U}_{37}^{\mathrm{K}}$ index [Brassell et al., 1986; Müller et al., 1998; Rosell-Melé et al., 1995b]. Comparison between these results and existing records for global ice volume change allows us to investigate links between high-latitude surface ocean circulation and the Northern Hemisphere ice sheets across the MPT.

\section{Methods}

\subsection{Site Locations}

[6] Site $983 \mathrm{C}\left(60^{\circ} 24^{\prime} \mathrm{N}, 23^{\circ} 38^{\prime} \mathrm{W}\right)$ was drilled at a water depth of $1985 \mathrm{~m}$ on the Bjorn-Gardar Drift in the northern North Atlantic as part of ODP Leg 162 [Jansen et al., 1996]. Surface waters at the site are presently influenced by an extension of the North Atlantic Current, the Irminger Current, which flows westward toward East Greenland [Hansen and Østerhus, 2000]. Lying south of the Arctic Front, seasonal SSTs range between 8 and $11^{\circ} \mathrm{C}$, around an annual mean value of $\sim 9^{\circ} \mathrm{C}$ [Conkright et al., 2002]. The sediments have relatively low organic carbon $(<0.48 \%)$ and carbonate $(<40 \%)$ contents, being dominated instead by fine-grained terrigenous particles advected by the overflow of Norwegian Sea Overflow Water (NSOW) across the
Greenland-Scotland Ridge and driving high sedimentation rates $\left(>16 \mathrm{~cm} \mathrm{ka}^{-1}\right)$. Variable contributions from iceberg rafting also occur [Jansen et al., 1996].

[7] Site $882\left(50^{\circ} 21^{\prime} \mathrm{N}, 167^{\circ} 35^{\prime} \mathrm{E}, 3244 \mathrm{~m}\right.$ water depth) was drilled on the Detroit Seamount in the northwest Pacific as part of ODP Leg 145 [Rea et al., 1993]. A continuous record spanning the Plio-Pleistocene was obtained by splicing Holes 882A and 882B [Tiedemann and Haug, 1995]. The site is located to the north of the modern Subarctic Front, that lies between 40 and $50^{\circ} \mathrm{N}$ [Yuan and Talley, 1996], and below the relatively cool southward flowing Oyashio Current, that meets the warmer Kuroshio Current at $\sim 40^{\circ} \mathrm{N}$. A permanent halocline in the region of the site reduces exchange between the surface and deep ocean [Tabata, 1975], and as a result causes a large annual SST range, from 1 to $12^{\circ} \mathrm{C}$ [Conkright et al., 2002]. Pleistocene sediments from Site 882 are composed of a diatom ooze and clayey diatom ooze [Rea et al., 1993]. Diatom concentrations range from 50 to $100 \%$. Carbonate is generally absent although in some intervals can represent up to $40 \mathrm{wt}$. \% of the sediment [Haug et al., 1995; Rea et al., 1993]. For the interval of study here, sedimentation rates range from 1.5 to $8 \mathrm{~cm} \mathrm{ka}^{-1}$ [Tiedemann and Haug, 1995], lower than at Site 983 but still suitable for the identification of orbital-scale oscillations.

\subsection{Age Models}

[8] A sampling interval of $5 \mathrm{ka}$ was selected at both sites. At Site 983 the benthic $\delta^{18} \mathrm{O}$ stratigraphy was used as the age model [Channell and Kleiven, 2000; Raymo et al., 2004]. Poor preservation of carbonate in many intervals prevented the application of an isotopic age model to Site 882 [Haug et al., 1995]. Magnetostratigraphy and subsequent tuning of GRAPE density oscillations to the precession band of the $65^{\circ} \mathrm{N}$ summer insolation provided an astronomically calibrated stratigraphy [Rea et al., 1993; Tiedemann and Haug, 1995]. Both age models suffered correlation problems between 1.2 and $1.3 \mathrm{Ma}$, because of anomalous magnetic susceptibility values (Site 882 [Tiedemann and Haug, 1995]) and poor carbonate preservation (Site 983 [Raymo et al., 2004]). We acknowledge that differences in the accuracy and precision between these age models limits the detailed comparison of leads and lags between the two sites, i.e., at orbital and shorter timescales. However, the records do allow us to compare and contrast long-term $(>\mathrm{G}-\mathrm{IG})$ trends in surface ocean properties associated with the MPT.

\subsection{Alkenone Analyses}

[9] Alkenones were obtained using repeated sonication of freeze-dried and homogenized sediments using dichloromethane and methanol $(3: 1, \mathrm{v} / \mathrm{v})$. All extracts were derivatized using bis(trimethylsilyl)triflouroacetamide (Sigma Aldrich) prior to instrumental analysis. Samples from Site 983 were quantified using a Fisons 8000 gas chromatograph fitted with a flame ionization detector (GC-FID) following the procedures described in detail by McClymont and RosellMelé [2005]. A selection of samples from Site 983 and all of the Site 882 samples were analyzed using gas chromatography-chemical ionization mass spectrometry 


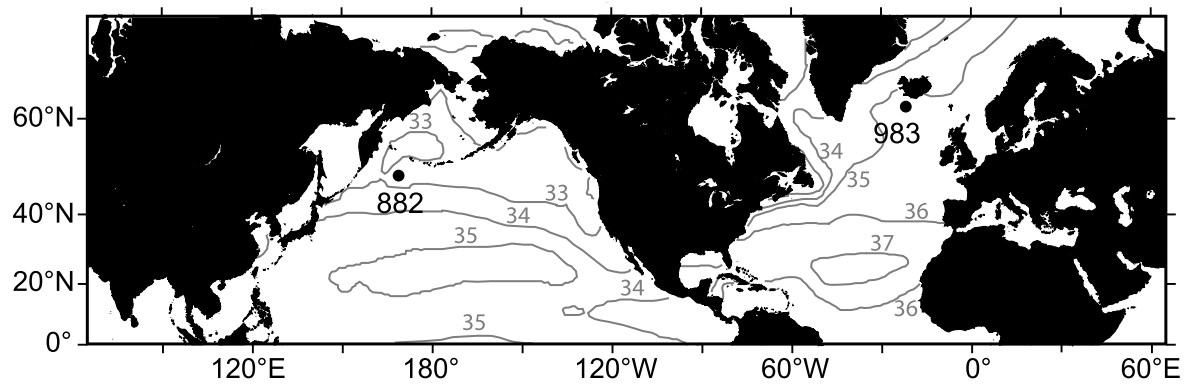

Figure 1. Location map for Sites 882 (northwest Pacific) and 983 (North Atlantic). Sea surface salinity contours shown in gray, from Conkright et al. [2002].

(GC-CI-MS), which is more sensitive than GC-FID [RosellMelé et al., 1995a].

[10] The relative abundance of the $\mathrm{C}_{37: 4}$ alkenone is expressed as a percentage of total $\mathrm{C}_{37}$ alkenones, $\% \mathrm{C}_{37: 4}$ [Rosell-Melé et al., 2002]. The $\mathrm{U}_{37}^{\mathrm{K}}$ and $\mathrm{U}_{37}^{\mathrm{K}^{\prime}}$ indices were calculated according to the relative concentrations of the di-, tri- and tetra-unsaturated $\mathrm{C}_{37}$ alkenones [Brassell et al., 1986; Prahl and Wakeham, 1987]:

$$
\begin{aligned}
\mathrm{U}_{37}^{\mathrm{K}} & =\left[\mathrm{C}_{37: 2}-\mathrm{C}_{37: 4}\right] /\left[\mathrm{C}_{37: 2}+\mathrm{C}_{37: 3}+\mathrm{C}_{37: 4}\right] \\
\mathrm{U}_{37}^{\mathrm{K}^{\prime}} & =\left[\mathrm{C}_{37: 2}\right] /\left[\mathrm{C}_{37: 2}+\mathrm{C}_{37: 3}\right]
\end{aligned}
$$

[11] SSTs were calculated using the global calibration for $\mathrm{U}_{37}^{\mathrm{K}^{\prime}}$ [Müller et al., 1998] that is calibrated against mean annual SSTs at the ocean surface, and the North Atlantic core top calibration for $\mathrm{U}_{37}^{\mathrm{K}}$ [Rosell-Melé et al., 1995b] calibrated using summer SSTs.

\section{Results and Discussion}

\subsection{Evaluation of the Alkenone Proxy Records}

[12] Modern calibration exercises have demonstrated that high $\% \mathrm{C}_{37: 4}$ values in both particulate organic matter and surface sediments are associated with low-temperature and low-salinity surface water masses of the Arctic and Polar Water domains [Bendle and Rosell-Melé, 2004; Bendle et al., 2005; Harada et al., 2006; Sicre et al., 2002]. Thus, $\% \mathrm{C}_{37: 4}$ in sediments exceeds $5 \%$ below Arctic Atlantic Waters (north of the Arctic Front, delineated using the 35 p.s.u. isoline), with very high concentrations at over $28-30 \%$ in Polar Atlantic Waters (north of the Polar Front, 34.2 p.s.u. isocline) [Bendle et al., 2005]. However, the multivariate control over $\% \mathrm{C}_{37: 4}$ by salinity and temperature prevents the application of $\% \mathrm{C}_{37: 4}$ to quantify past SSS or SSTs [Bendle et al., 2005]. High concentrations of $\mathrm{C}_{37: 4}$ are associated with the cooler and fresher water masses found in the Pacific subarctic [Harada et al., 2006]. The correlation between $\% \mathrm{C}_{37: 4}$ and SSS in the Pacific subarctic was strong $\left(\mathrm{R}^{2}=0.76\right)$, although the relationship was insignificant for $\% \mathrm{C}_{37: 4}$ versus SST $\left(\mathrm{R}^{2}=0.17\right.$; [Bendle et al., 2005; Harada et al., 2006]). A calibration exercise for $\% \mathrm{C}_{37: 4}$ comparable to those undertaken in the Atlantic using surface sediments has not been performed in the northern Pacific; thus, we do not apply the $\% \mathrm{C}_{37: 4}$ proxy as a method of quantifying past SSS or SST. At both sites examined here, we apply ${ }_{0} \mathrm{C}_{37: 4}$ to reconstruct the past presence of cool and fresh arctic (Atlantic) and subarctic (Pacific) water masses at the sites of interest.

[13] The MPT is a time of biotic as well as climatic evolution, and thus it needs to be considered whether longterm trends in the $\% \mathrm{C}_{37: 4}$ signature reflect evolutionary change in the alkenone-synthesizing Haptophyte algae rather than a biochemical response to surface oceanography. As Emiliania huxleyi did not evolve until the late Pleistocene [Thierstein et al., 1977], alternative species must be responsible for alkenone production at the MPT, and seem likely to include members of the Geophyrocapsa genus that follow the modern $\mathrm{U}_{37^{\prime}}^{\mathrm{K}^{\prime}}$-SST relationship [Marlowe et al., 1990] and that dominate the mid-Pleistocene sediments from Site 983 (E. L. McClymont, unpublished data, 2004). This issue has been tackled before either for the late Pleistocene or the MPT in the southeast Atlantic. In all instances evolutionary changes in coccolith assemblages had no apparent impact upon the distributions of alkenones, and by inference the response of the alkenone indices to SST [McClymont et al., 2005 , and references therein]. In their investigation of the $\% \mathrm{C}_{37: 4}$ proxy, Bendle et al. [2005] argued that E. huxleyi remained the prime candidate for the synthesis of alkenones and for the $\% \mathrm{C}_{37: 4}$ response to water mass properties, given positive correlations between alkenone concentrations and E. huxleyi abundance, and the fact that the only alternative calcifying coccolithophore in the region, Coccolithus pelagicus, does not synthesize alkenones. Thus, the decline of C. pelagicus between 1.65 and $1.0 \mathrm{Ma}$ at Site 982 [Baumann and Huber, 1999], even if it were replicated at Site 983, could not account for any observed $\% \mathrm{C}_{37: 4}$ trends. Moreover, no significant change to total coccolith accumulation rates across the MPT were observed at Site 982 [Baumann and Huber, 1999], nor in a low-resolution investigation at Site 983 (E. L. McClymont, unpublished data, 2004).

[14] This issue can be investigated further if one applies a suite of indices recording the relative abundances of the $\mathrm{C}_{37}$ and $\mathrm{C}_{38}$ alkenones at Site 983 following the methodology of McClymont et al. [2005]. Unfortunately, $\mathrm{C}_{38}$ alkenones were not measured in Site 882 sediments. These indices have an empirical basis in the same manner as the $\mathrm{U}_{37}^{\mathrm{K}}-\mathrm{SST}$ 


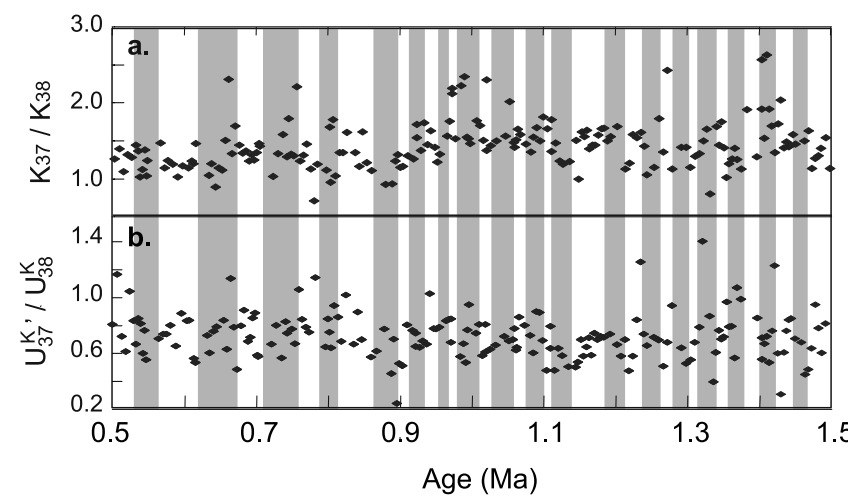

Figure 2. Alkenone distributions at Site 983 between 0.5 and 1.5 Ma. Glacial stages are marked by the vertical gray shading. (a) Ratio of total concentration of $\mathrm{C}_{37}$ alkenones to total concentration of $\mathrm{C}_{38}$ alkenones (K37/K38; Prahl et al. [1988]). (b) Ratio of the $\mathrm{U}_{37}^{\mathrm{K}^{\prime}}$ index of SST to the $\mathrm{U}_{38}^{\mathrm{K}}$ index. The $\mathrm{U}_{38}^{\mathrm{K}}$ index is defined as $\left[\mathrm{C}_{38: 2} \mathrm{Me}\right]+\left[\mathrm{C}_{38: 2} \mathrm{Et}\right] /$ $\left[\mathrm{C}_{38: 2} \mathrm{Me}\right]+\left[\mathrm{C}_{38: 2} \mathrm{Et}\right]+\left[\mathrm{C}_{38: 3} \mathrm{Me}\right]+\left[\mathrm{C}_{38: 3} \mathrm{Et}\right][$ Rosell-Melé et al., 1994].

relationship [Conte et al., 2001; Prahl et al., 1988; RosellMelé et al., 1995b], and are thought to reflect the provenance of the alkenones from diverse species or coccolithophorid biogeographic provinces. Figure 2 demonstrates that the K37/K38 [Prahl et al., 1988] and $\mathrm{U}_{37}^{\mathrm{K}^{\prime}} / \mathrm{U}_{38}^{\mathrm{K}}$ indices [RosellMelé et al., 1994] fall within a restricted range throughout the interval of study, and that no shifts in values are observed that could account for any glacial-interglacial nor longer-term trends in $\% \mathrm{C}_{37: 4}, \mathrm{U}_{37}^{\mathrm{K}}$ or $\mathrm{U}_{37}^{\mathrm{K}^{\prime}}$ at Site 983 . Thus, the distributions of alkenones suggests that the alkenone producers across the MPT interval had a biochemical response to oceanographic conditions analogous to that of modern species, and therefore that the observed changes in $\% \mathrm{C}_{37: 4}, \mathrm{U}_{37}^{\mathrm{K}}$ and $\mathrm{U}_{37}^{\mathrm{K}^{\prime}}$ reflect oceanographic trends.

[15] In most oceanographic settings, the $\mathrm{C}_{37: 4}$ alkenone is absent and SSTs are reconstructed using the simplified form of the alkenone index, $\mathrm{U}_{37}^{\mathrm{K}^{\prime}}$ [Prahl and Wakeham, 1987]. However, this index has been problematic to correlate to SSTs at high latitudes of the Northern Hemisphere, in settings where the $\mathrm{C}_{37: 4}$ alkenone is in high concentration [Bendle and Rosell-Melé, 2004; Rosell-Melé, 1998; RosellMelé et al., 1995b]. In fact, in the northern North Atlantic, the $\mathrm{U}_{37}^{\mathrm{K}}$ index has shown a more robust temperature dependence than $\mathrm{U}_{37}^{\mathrm{K}^{\prime}}$ except in Arctic or polar water domains, when both indices appear to cease to be SST dependent [Bendle and Rosell-Melé, 2004; Rosell-Melé, 1998]. In recognition of these uncertainties, we focus upon the $U_{37^{-}}^{K}$ derived SSTs, generated using the North Atlantic core top calibration to summer SSTs [Rosell-Melé et al., 1995b]. For Site 983 , we also show results from $\mathrm{U}_{37}^{\mathrm{K}^{\prime}}$ for comparison, using the global mean annual SST calibration [Müller et al., 1998]. We acknowledge that under conditions of high ${ }_{0} \mathrm{C}_{37: 4}$ the $\mathrm{U}_{37}^{\mathrm{K}}$ and $\mathrm{U}_{37}^{\mathrm{K}^{\mathrm{C}}}$ indices are used most effectively in combination with $\% \mathrm{C}_{37: 4}$ to qualitatively trace the dominant overlying water mass domain, rather than to quantify SST.

\subsection{Site 983 (North Atlantic)}

[16] Records of alkenone indices $\left(\% \mathrm{C}_{37: 4}\right.$ and $\left.\mathrm{U}_{37}^{\mathrm{K}}\right)$ from Site 983 are shown in Figures $3 b$ and 3c. Site 983 is ideally positioned to register changes in the position of the Arctic Front and thus the extent of the Arctic water mass in the North Atlantic. This has been demonstrated in previous examinations of Site 983 sediments and of its closest neighbor, Site 984, using diatoms and foraminifera respectively [Koç et al., 1999; Wright and Flower, 2002]. The sensitive location of Site 983 may account for the high degree of variability in SSTs and ${ }^{2} \mathrm{C}_{37: 4}$ within glacial/ interglacial stages. Alkenone concentrations (sum of $\mathrm{C}_{37}$ molecules) ranged between $30 \mathrm{ng} \mathrm{g}^{-1}$ to $1.5 \mu \mathrm{g} \mathrm{g}^{-1}$, with an average concentration of $\sim 350 \mathrm{ng} \mathrm{g}^{-1}$. Both records reveal considerable variability within glacial and interglacial intervals, although glacials are largely marked by high concentrations of $\mathrm{C}_{37: 4}$ and low SSTs. As shown for the last glacial period in the North Atlantic, the $\% \mathrm{C}_{37: 4}$ record in the site is bound to contain a suborbital variability linked to the occurrence of Heinrich events [Bard et al., 2000; RosellMelé, 1998]. Together with the sampling resolution across the 1 My interval of study limiting significant signal detection, and the noisy nature of the short-term signals given the sensitivity of this site to rapid changes in surface current locations, such processes would explain the lack of a clear glacial to interglacial variability in the records.

[17] The $\% \mathrm{C}_{37: 4}$ at Site 983 ranges between zero, particularly during interglacial maxima, and a maximum of $24 \%$ at $\sim 1.0 \mathrm{Ma}$. On Figure 3, the line denoting $\mathrm{C}_{37: 4}$ concentrations of $5 \%$ is used to delineate Atlantic waters from the Arctic and Polar water masses on the basis of modern calibrations as discussed above [Bendle and Rosell-Melé, 2004; Rosell-Melé et al., 1998]. Between 1.15-0.86 Ma (marine oxygen isotope stage (MIS) 34-21), concentrations of $\mathrm{C}_{37: 4}$ rarely fall below 5\% even during interglacials, which we interpret as evidence for the dominance of polar/ arctic waters at the core site during this interval. This trend occurs despite no notable shift in the benthic $\delta^{18} \mathrm{O}$ record from Site 983 (Figure 3a). After $0.9 \mathrm{Ma},{ }_{0} \mathrm{C}_{37: 4}$ returned to low or undetectable concentrations during interglacials, but in contrast to the early part of the record, concentrations of $\mathrm{C}_{37: 4}$ continued to reach $10-15 \%$ during colder intervals. One exception to this trend is the high $\mathrm{C}_{37: 4}$ concentrations during the later stages of MIS 21, when $\delta^{18} \mathrm{O}$ indicates relatively warm and/or low ice volume conditions. However, high abundances of the polar water foraminifer Neogloboquadrina pachyderma (s.) (Figure 4) [Wright and Flower, 2002], support the inference made from the $\% \mathrm{C}_{37: 4}$ data that cooler and fresher waters prevailed at Site 983 at this time.

[18] The range of reconstructed SSTs using $U_{37}^{K}$ at Site 983 is consistent with reconstructed winter and summer SSTs at the last glacial maximum (around $1-4^{\circ} \mathrm{C}$ ) [Pflaumann et al., 2003] and with the modern annual SST range at the site (8$11^{\circ} \mathrm{C}$ ) [Conkright et al., 2002]. SSTs using $\mathrm{U}_{37}^{\mathrm{K}^{\prime}}$ are higher than those from $U_{37}^{K}$. This is a consequence of the inclusion in $\mathrm{U}_{37}^{\mathrm{K}}$ of the $\mathrm{C}_{37: 4}$ alkenone. There is no clear secular trend in SSTs from either proxy across the interval of study, and clear glacial-interglacial oscillations are not well defined because of considerable suborbital variability and the rela- 


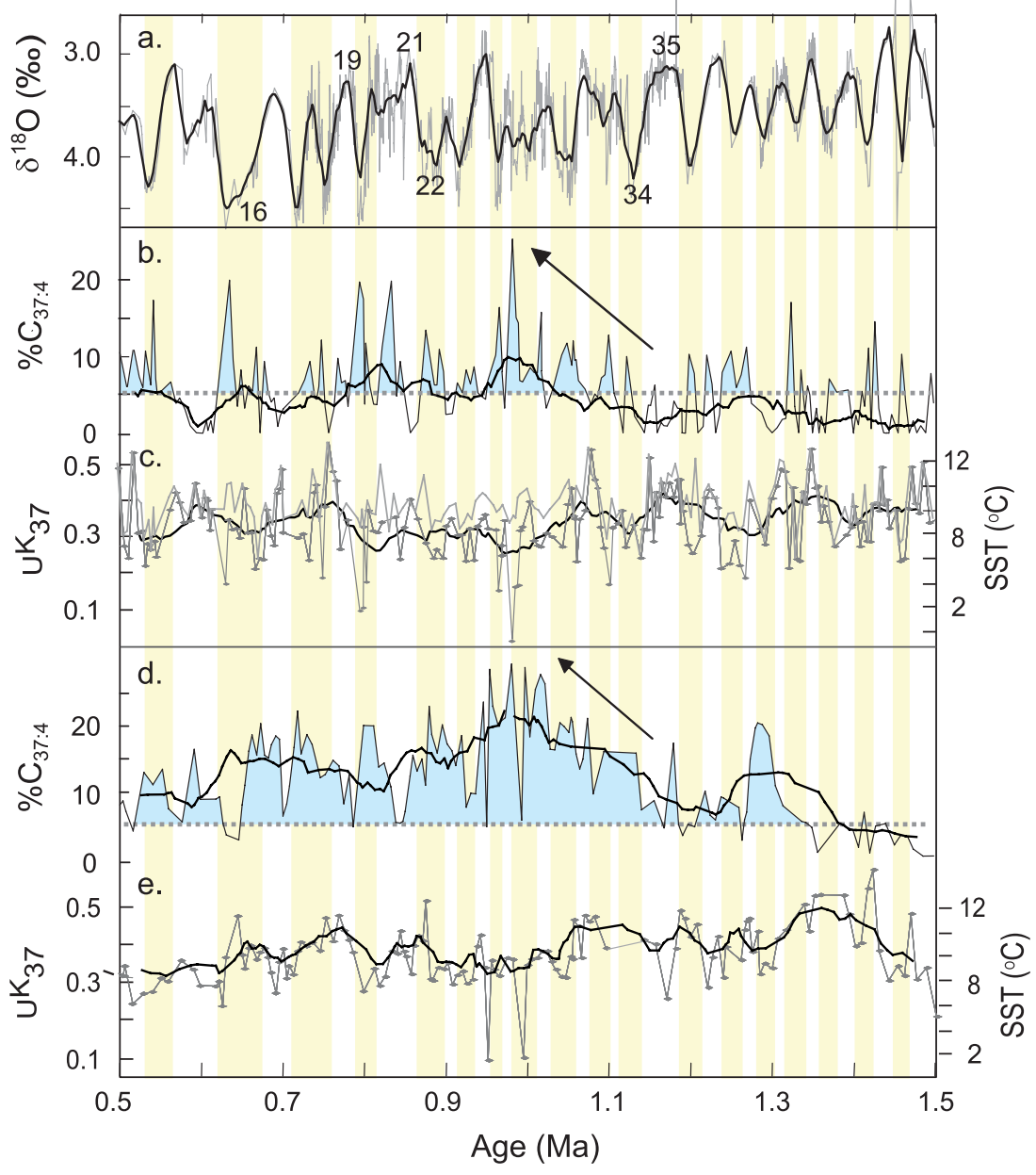

Figure 3. (a) Benthic $\delta^{18} \mathrm{O}$ record from Site 983, smoothed to $3 \mathrm{ka}$ as described by Raymo et al. [2004]. Glacial stages are marked by the vertical yellow shading, and selected marine isotope stages discussed in the text are marked. The MPT as defined by Mudelsee and Schulz [1997], on the basis of variations to global ice volume, spans MIS $21-16$. (b) Relative abundance of the $\mathrm{C}_{37: 4}$ alkenone $\left({ }_{0} \mathrm{C}_{37: 4}\right)$ from Site 983 , North Atlantic. Black line shows running mean at 10 point ( $\sim 50 \mathrm{ka})$. The long-term increase in $\% \mathrm{C}_{37: 4}$ is highlighted by the arrow. $\mathrm{C}_{37: 4}=5 \%$ is indicated by the horizontal dashed line. (c) Dark gray series: $U_{37}^{K}$-derived SSTs from Site 983, North Atlantic. Running mean at 10 point ( $\sim 50$ ka, black line). Light gray: $U_{37}^{K^{\prime}}$ time series for comparison, shown on $U_{37}^{K}$ scale. (d) Relative abundance of the $C_{37: 4}$ alkenone $\left(\% \mathrm{C}_{37: 4}\right)$ from Site 882 , northwest Pacific. Running mean at 10 point ( $\left.\sim 50 \mathrm{ka}\right)$ and annotation as for Figure 3b. (e) $\mathrm{U}_{37}^{\mathrm{K}}$-derived SSTs from Site 882, northwest Pacific. Running mean at 10 point ( $\sim 50 \mathrm{ka}$, black line).

tively low sampling resolution. Given that SSTs from $\mathrm{U}_{37}^{\mathrm{K}}$ are not independent from the $\% \mathrm{C}_{37: 4}$ record, the relatively cool interglacials between 1.15 and $0.86 \mathrm{Ma}$ (MIS 34-21) do in part reflect the sustained high $\% \mathrm{C}_{37: 4}$ values at this time (Figure 3). However, such interdependence is not necessarily problematic, as this combination of high $\% \mathrm{C}_{37: 4}$ and low $\mathrm{U}_{37}^{\mathrm{K}}$ values is consistent with the presence of arctic and polar water masses at Site 983 on the basis of modern observations. The alternative, to use $\mathrm{U}_{37}^{\mathrm{K}^{\prime}}$ as a record of past SSTs, is hampered by the relatively poor correlations between these variables at low temperatures and with high $\% \mathrm{C}_{37: 4}$ in modern calibrations (discussed above).
[19] The high sedimentation rates of Site 983 result from the advection of fine-grained terrigenous particles by bottom currents originating in the Nordic Seas. Conversely, there is some evidence for the removal of the fine carbonate fraction on the Gardar and Hatton Drifts under stronger NSOW flow [Wang and McCave, 1990]. Thus, the accumulation of alkenones and other marine organic matter on the Gardar drift could reflect a combination of both production in the overlying ocean and addition as well as removal of fine sediment fractions by the bottom currents. We have not addressed this issue in the current paper, and have interpreted our records as representing autochthonous signals. The NSOW flow speed has varied at orbital scales, but we 


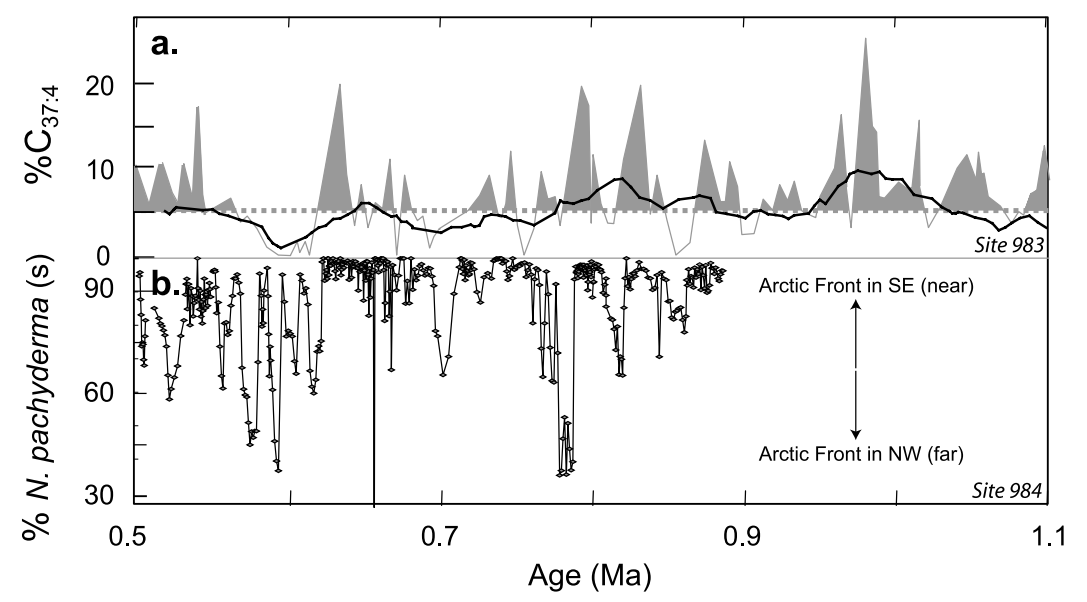

Figure 4. Comparison between alkenone and foraminifer indicators of water mass positions in the North Atlantic between 1.1 and $0.5 \mathrm{Ma}$. (a) Relative abundance of the $\mathrm{C}_{37: 4}$ alkenone $\left(\% \mathrm{C}_{37: 4}\right)$ from Site 983, North Atlantic. Shading marks $\% \mathrm{C}_{37: 4}>5 \%$, as in Figure 3. (b) Percentage of the Arctic Front indicator species Neogloboquadrina pachyderma (s) from Site 984 between 0.9-0.5 Ma. Data and noted interpretation of Arctic Front position relative to the core site is from Wright and Flower [2002].

argue that its variability cannot account for the secular trends in $\% \mathrm{C}_{37: 4}$ that are observed at this site and the offsets in the trends with the $\delta^{18} \mathrm{O}$ foraminiferal record. The maximum temporal offset between organic and carbonate materials of $1-5 \mathrm{ka}$ on the Bjorn-Gardar drift (J. Holtvoeth, personal communication, 2007) does not explain a shift toward higher $\% \mathrm{C}_{37: 4}$ values that is sustained beyond orbital variations. Nor is there evidence that the mean strength of NSOW changed from 1.15 Ma, alongside the increase in $\% \mathrm{C}_{37: 4}$. The mid-Pleistocene record of Wang and McCave [1990] extended back to $\sim 1 \mathrm{Ma}$, and thus does not record the response of NSOW strength to the onset of the MPT. Glacial NADW may become weaker after 1.2 Ma [Gröger et al., 2003; Oppo et al., 1995], although the most pronounced reduction in glacial NADW strength has been reported from $0.95 \mathrm{Ma}$ [Gröger et al., 2003; Kleiven et al., 2003; Schmieder et al., 2000]. In light of the available evidence, we propose that changes to bottom current strength and the corresponding sediment advection or reworking processes can therefore not account for the long-term trends in $\% \mathrm{C}_{37: 4}$ identified here as associated with the MPT.

\subsection{Site 882 (Northwest Pacific)}

[20] Absolute alkenone concentrations were not quantified in this site, because as they were below the detection limit of the GC-FID in most intervals, GC-CIMS was used instead, which does not allow their absolute quantification. The $\% \mathrm{C}_{37: 4}$ results from Site 882 are shown in Figures $3 \mathrm{~d}$ and $3 \mathrm{e}$. Concentrations of $\mathrm{C}_{37: 4}$ range between $<1 \%$ and $\mathrm{a}$ maximum of $29 \%$ at $1.0 \mathrm{Ma}$. Lowest $\% \mathrm{C}_{37: 4}$ are found prior to $1.35 \mathrm{Ma}$ (MIS 43). In general, $\% \mathrm{C}_{37: 4}$ minima tend to occur during cold isotopic stages or when SSTs are low, but the correlation is less clear than at Site 983 and may in part reflect the difference in age model determination. One of the most striking results from Site 882 results is the secular increase in $\mathrm{C}_{37: 4}$ concentrations after $\sim 1.2 \mathrm{Ma}$, which reached a maximum at $1.0 \mathrm{Ma}$ before values fell progressively until $0.5 \mathrm{Ma}$. Relatively high $\% \mathrm{C}_{37: 4}$ values are recorded for a short interval centered on $\sim 1.3 \mathrm{Ma}$; we note that this falls within the $100 \mathrm{ka}$ window of relatively weak age control and so its absolute age may vary. The SST time series is not marked by any strong cooling/warming events throughout the interval of study, and clear glacial-interglacial variability is not reflected in the record, probably owing to the low sampling resolution. A progressive decline toward cooler mean SSTs can be detected (Figure 3e). From a PlioPleistocene perspective, the increase in $\mathrm{C}_{37: 4}$ from $1.2 \mathrm{Ma}$ is significant for the longer-term history of Site 882, given that this marks the first time that $\% \mathrm{C}_{37: 4}$ exceeded $10 \%$ for the $6 \mathrm{Ma}$ record at this site [Haug, 1996].

\subsection{Position of the Arctic Front During the MPT}

[21] Both sites record an interval of prolonged high concentrations of $\mathrm{C}_{37: 4}$ between 1.2 and $0.9 \mathrm{Ma}$ and synchronous maximum concentrations at $1.0 \mathrm{Ma}$. We interpret the high concentrations of $\% \mathrm{C}_{37: 4}$ at Sites 983 and 882 as evidence for the presence of relatively cool and fresh surface waters. Thus the ${ }_{0} \mathrm{C}_{37: 4}$ trends in Figure 3 reflect an equatorward expansion of arctic/polar water masses in the Atlantic and Pacific Oceans from 1.15 Ma that spanned both glacials and interglacials. For the North Atlantic, this interpretation is supported (Figure 4) by the correlation between the peaks in $\% \mathrm{C}_{37: 4}$ at Site 983 to the intervals dominated by the polar planktonic foraminifer $N$. pachyderma (s.) at Site 984, for the time interval over which these two records overlap (1.0-0.6 Ma) [Wright and Flower, 2002]. The difference in age models, the high degree of variability in ${ }_{0} \mathrm{C}_{37: 4}$ and $\mathrm{SST}$ within both glacial and interglacial stages, and the potential for advection-induced temporal offsets at Site 983, limit our ability to investigate leads and lags 
between sites. We therefore choose to focus here upon discussion of the similar long-term trends in $\% \mathrm{C}_{37: 4}$ that characterize the two sites.

[22] Although the maxima in $\%_{37: 4}$ at $1.0 \mathrm{Ma}$ are easy to identify at both sites, the onset of the increasing $C_{37: 4}$ concentrations is less clear to define. Figure 3 places the secular increase in $\mathrm{C}_{37: 4}$ at both sites at between 1.15 and $1.2 \mathrm{Ma}$, although $\% \mathrm{C}_{37: 4}$ was not sustained above $5 \%$ until circa $1.1 \mathrm{Ma}$ at Site 983 . After 1.0 Ma, the mean $\% \mathrm{C}_{37: 4}$ at both sites declined. At Site 983 this was particularly marked during warm stages, suggesting that the Arctic Front returned to a more northerly position than experienced during the 1.15-1.0 Ma interval. This likely reflects a renewed influence of warm Atlantic waters to the site during periods of low ice volume. In contrast, the $\% \mathrm{C}_{37: 4}$ maxima continued to remain relatively high $(>10 \%)$, indicating that the relatively extensive arctic/polar water masses that developed between 1.2 and $0.9 \mathrm{Ma}$ were maintained after 0.9 Ma in the North Atlantic during cooler stages. Site 983 thus appears to have been the subject of greater variability in surface ocean properties after $0.9 \mathrm{Ma}$ than in the interval preceding 1.2 Ma. In the northwest Pacific, the secular retreat of subarctic waters after $0.9 \mathrm{Ma}$ is reflected in falling $\% \mathrm{C}_{37: 4}$ during both glacials and interglacials. Values remain higher than those prior to $1.3 \mathrm{Ma}$, and thus the extent of cooler and fresh surface water masses in the northwest Pacific also remained relatively large even after the maximum at 1.0 Ma. The pronounced variability in $\% \mathrm{C}_{37: 4}$ after $0.9 \mathrm{Ma}$ that is observed at Site 983 is not replicated at Site 882 , the latter recording a more gradual return to low mean $\% \mathrm{C}_{37: 4}$ values.

[23] The results presented here thus indicate two significant changes to the distribution of water masses in the North Atlantic and northwest Pacific associated with the MPT: (1) between 1.2-0.9 Ma, a secular shift toward more expansive subarctic/subpolar water masses and (2) from $0.9 \mathrm{Ma}$, a partial retreat of subarctic/subpolar water masses. At Site 983 maxima in $\% \mathrm{C}_{37: 4}$ continue to exceed those which occurred before 1.2 Ma, suggesting that the maximum extent of the arctic/polar water masses on orbital timescales was greater after the MPT. As our time series do not continue from $0.5 \mathrm{Ma}$ to the present day, we cannot conclusively demonstrate that the retreat of the subarctic/ subpolar water masses after $0.9 \mathrm{Ma}$ was a permanent one at either site. We have noted above that our $\% \mathrm{C}_{37: 4}$ record at Site 983 is closely aligned with the N. pachyderma (s.) record from Site 984 [Wright and Flower, 2002]. The latter study demonstrated that a relatively southern position of the Arctic Front in the North Atlantic was maintained between 1.0 and $0.6 \mathrm{Ma}$, after which the interglacial position of the Arctic Front achieved the southwest to northeast alignment that is found at the present day. Furthermore, an increasing contribution of biogenic carbonate to Site 985 from $0.65 \mathrm{Ma}$ marks incursions of warm, Atlantic waters to the Norwegian Sea [Baumann and Huber, 1999]. The Wright and Flower [2002] record does not extend back prior to $1.0 \mathrm{Ma}$, but our data in Figure 3 would suggest that the secular migration of the Arctic Front southward began from 1.2 Ma, as part of the MPT. This proposal is further supported by the Nordic Seas foraminiferal record of Helmke et al. [2003a], who identified an intensification of glacial conditions after 1.2 Ma. At Site 985, inputs of biogenic carbonate were rare between 1.1 and $0.65 \mathrm{Ma}$, marking occasional inputs of Atlantic waters to the Norwegian Sea during minima in ice volume [Baumann and Huber, 1999]. It is also interesting to note that the adaptation of $N$. pachyderma (s). to the cold polar water environment developed from 1.1 Ma [Baumann and Huber, 1999; Henrich et al., 2002; Meggers and Baumann, 1997], as reflected in a net increase in shell size over the last 1.3 Ma. Cooler and more arid conditions in Europe around 1.0 Ma are also reflected in records of biotic change, including the shift toward cold climate adapted mammalian fauna associated with the end-Villafranchian event [Azzaroli, 1995] and the development of colder floral assemblages [e.g., Bertini, 2003] from 1.2 Ma onward.

[24] In the northwest Pacific, the partial reduction in $\% \mathrm{C}_{37: 4}$ cannot be explained by incursions from a warm current as seen in the Atlantic, because of its position within the subarctic water mass and isolation from the Subarctic Front. The $\mathrm{C}_{37: 4}$ time series indicates a partial retreat or increased salinity of the subarctic water masses after $1.0 \mathrm{Ma}$, although still within a cool and fresh subarctic environment. The cause of this change to surface conditions is unclear. Ice-rafted detritus (IRD) accumulation rates at Site 882 do not change across the MPT, precluding this process as an explanation for altered freshwater inputs [St. John and Krissek, 1999]. Although insolation at $65^{\circ} \mathrm{N}$ peaks during MIS 25, circa $0.94 \mathrm{Ma}$ [Berger and Loutre, 1991] because of high eccentricity, the rising limb of $\% \mathrm{C}_{37: 4}$ occurs during the previous eccentricity peak, suggesting that North Pacific water mass distribution is not controlled by insolation. At present, the distinctive salinity maximum of the subarctic gyre is linked to the excess precipitation that results from the strong Aleutian low-pressure system and the resulting winter storms and reduced cloud cover [Sancetta and Silvestri, 1986]. A weaker East Asian winter monsoon between MIS 22-16 is consistent with weaker Aleutian low-pressure and Siberian high-pressure systems [Heslop et al., 2002], but occurs after the decline in $\% \mathrm{C}_{37: 4}$ and thus cannot be considered as a forcing mechanism. Modern teleconnections also suggest that the precipitation-bearing westerlies might be reduced under a strengthening of Walker circulation [Alexander et al., 2002], the latter observed across the MPT [McClymont and Rosell-Melé, 2005]. However, the complex extratropical response to ENSO variability within our present climate system limits acceptance of this mechanism. Analysis of diatom assemblages across the North Pacific has shown that between 1.0 and $0.8 \mathrm{Ma}$, in parallel with the reduction in $\% \mathrm{C}_{37: 4}$ shown in Figure 3, the western Pacific experienced enhanced climate variability [Sancetta and Silvestri, 1986]. This variability included periodic migrations of the Subarctic Front over several degrees of latitude and an enhanced variability in the subarctic Pacific between intervals of stronger and weaker seasonal contrasts [Sancetta and Silvestri, 1986]. We propose here that this increased variability most likely accounts for the partial decrease in $\% \mathrm{C}_{37: 4}$ after 1.0 Ma, as the cool and fresh conditions were no longer sustained. Sancetta and Silvestri [1986] attributed this variability to east-west shifts between the Siberian high- 
pressure and Aleutian low-pressure cells, but the cause is unclear.

\subsection{Implications for Ice Sheet Growth}

[25] The development of cooler and fresher high-latitude surface oceans in the North Atlantic and Pacific Oceans is not mirrored by a similar expansion of the Northern Hemisphere ice sheets. There is evidence, nevertheless, for advance of the Scandinavian ice sheet at around 1.1 Ma [Sejrup et al., 2000] and significant increases in IRD in the North Atlantic and Nordic Seas after 1.0 Ma [Fronval and Jansen, 1996; Ruddiman et al., 1986]. Mean global ice volume, however, underwent a later stepwise increase during the intense glacial cooling of MIS 22 $(0.9 \mathrm{Ma})$, the proposed onset of the MPT [Mudelsee and Schulz, 1997]. This suggests that there was a delayed overall response in the Northern Hemisphere ice sheets to cooling observed elsewhere in the climate system associated with the MPT. The results presented in Figure 3 thus demonstrate that knowledge of high-latitude climate changes cannot be determined through the benthic $\delta^{18} \mathrm{O}$ record alone, the latter signal giving a "late" date for the onset of the MPT at $\sim 0.9 \mathrm{Ma}$.

[26] We propose that the apparent delayed response in the Northern Hemisphere ice sheets is the consequence of changes in the supply of water vapor to boreal North America and Europe prior to $0.9 \mathrm{Ma}$, caused, at least in part, by the described equatorward expansion of arctic water masses. In the modern North Atlantic, arctic and polar water mass domains are associated with at least seasonal sea ice cover [Swift, 1986]. Figure 3 thus suggests that a shift toward more extensive sea ice cover occurred in the North Atlantic prior to $0.9 \mathrm{Ma}$, and that glacial sea ice cover continued to be relatively extensive until at least $0.6 \mathrm{Ma}$. Similarly, more extensive sea ice cover is suggested by an increasing presence of reddish sediments in the West Norwegian Sea between 1.2 and $0.9 \mathrm{Ma}$ [Helmke et al., 2003b]. By comparing benthic $\delta^{13} \mathrm{C}$ values in a suite of northern North Atlantic sites Raymo et al. [2004] identified more variable vertical $\delta^{13} \mathrm{C}$ gradients prior to $0.6 \mathrm{Ma}$, which they attributed to more extensive sea ice cover. In contrast to the records presented here, however, Raymo et al. [2004] found that the $\delta^{13} \mathrm{C}$ profiles were similar back to $1.8 \mathrm{Ma}$, earlier than the $1.2 \mathrm{Ma}$ expansion that our $\% \mathrm{C}_{37: 4}$ results indicate. More expansive sea ice cover would have been detrimental to ice sheet growth by limiting evaporation, increasing the surface ocean albedo, and deflecting storm tracks southward away from ice sheet source regions [Smith et al., 2003; Tziperman and Gildor, 2003].

[27] In the northwest Pacific we also detect a cooler and fresher surface ocean at Site 882 from 1.2 Ma (Figure 3). Here, the signal provided by $\% \mathrm{C}_{37: 4}$ records a slightly different scenario because of the oceanographic regime below which Site 882 was drilled. The stable and stratified water column that characterizes the region at the present day had already developed in association with the onset of Northern Hemisphere glaciation, circa $2.7 \mathrm{Ma}$ [Haug et al., 2005]. Unlike the North Atlantic site, Site 882 sits within subarctic waters and is not affected by latitudinal migrations of frontal systems over the site. Rather, the
$\% \mathrm{C}_{37: 4}$ results record changes to temperature and salinity that likely reflect variability in radiative heating, precipitation and mixing of the dominant hydrographic features [Endoh et al., 2004]. Even during glacial maxima of the late Pleistocene, Site 882 was likely located to the south of the perennial zone of sea ice [Jaccard et al., 2005], and, given the lack of a modern $\% \mathrm{C}_{37: 4}$ calibration in the Pacific, we cannot link the high concentrations of $\% \mathrm{C}_{37: 4}$ to the presence of sea ice at Site 882. Thus, Figure 3 indicates that the MPT was associated with cooling and freshening of the surface ocean within the stratified northwest Pacific. Elsewhere in the North Pacific, evidence for more extensive subarctic conditions can be found from 1.2 Ma. In the northwest, increased ice rafting at $1.0 \mathrm{Ma}$ occurred to the south of Site 882, but not at Site 882 itself [St. John and Krissek, 1999]. This has been linked to a more southerly position of the subarctic front and thus the zone of iceberg melting and deposition [Sancetta and Silvestri, 1986; St. John and Krissek, 1999]. In contrast, the most significant mid-Pleistocene change in the northeast Pacific is a marked increase in ice rafting from $0.9 \mathrm{Ma}$, attributed to the Alaskan signature of the expansion of Northern Hemisphere glaciation [Sancetta and Silvestri, 1986].

[28] The modest poleward retreat of the arctic/polar water masses in the North Atlantic and Pacific Oceans after $1.0 \mathrm{Ma}$, as detailed by the decrease in $\% \mathrm{C}_{37: 4}$ (Figure 3), would have removed or reduced the constrictions to ice sheet growth described above. Evidence to support this hypothesis include a shift toward an increased mean global ice volume [Mudelsee and Schulz, 1997], increasing severity of Scandinavian glaciations [Henrich and Baumann, 1994] and increased ice rafting from Alaskan and Greenland sources [Sancetta and Silvestri, 1986].

\subsection{Implications for the MPT}

[29] The expansion of cooler and fresher surface waters in both the North Atlantic and Pacific oceans from 1.2 Ma occurs alongside many other climate changes associated with the MPT. Specifically, these high northern latitude changes occur when intensification of the tropical and subtropical upwelling systems and increasing continental aridity have indicated more intense atmospheric circulation after 1.2 Ma [de Menocal, 1995; Durham et al., 2001; Heslop et al., 2002; Liu and Herbert, 2004; Marlow et al., 2000; McClymont and Rosell-Melé, 2005; Medina-Elizalde and Lea, 2005; Xiao and An, 1999]. The changing atmospheric circulation has been linked to an increasing meridional temperature gradient driven by circulation changes in the Southern Hemisphere, specifically by the equatorward migration of the Antarctic circumpolar current after $1.8 \mathrm{Ma}$ [McClymont and Rosell-Melé, 2005; McClymont et al., 2005], and/or increased sea ice cover in the Southern Ocean and its effects on the temperature of the upwelling waters [Lee and Poulsen, 2006]. We show here that the high latitudes of the Northern Hemisphere also underwent a cooling and freshening, which would have acted to increase further the meridional temperature gradient and drive more intense atmospheric circulation. These processes also ought to have encouraged ice sheet growth via increased moisture transport to the high latitudes [Raymo and Niscancioglu, 
2003] and/or by reducing atmospheric temperatures in the ice sheet source regions [Lee and Poulsen, 2006]. However, we hypothesize that this was countered by the negative feedbacks to moisture delivery imposed by more extensive cooler and fresher surface waters at high latitudes. Sayag et al. [2004] demonstrated hysteresis between sea ice cover and land ice extent, the latter increasing only when sea ice had a restricted extent. Furthermore, sea ice growth was also determined by the meridional temperature gradient, expanding when the temperature gradient was low. This notion of a "sea ice switch" mechanism, whereby sea ice expands rapidly and exerts a strong influence over land ice growth, has previously been argued to form a key element of the development of the $100 \mathrm{ka}$ cycles [Gildor and Tziperman, 2001; Tziperman and Gildor, 2003]. This argument finds support in the higher $\% \mathrm{C}_{37: 4}$ during glacial maxima after $0.9 \mathrm{Ma}$ at Site 983 (Figure 2b), highlighting a shift toward much greater sea ice extent in the North Atlantic during glacial maxima associated with the MPT and thus with the emergence of the $100 \mathrm{ka}$ cycles. However, further testing of this land/sea ice link beyond glacial/interglacial timescales and for the Northern Hemisphere ice sheets is required, given the focus in modeling studies of interannual [Weatherly, 2004], millennial [Sayag et al., 2004] and glacial [Gildor and Tziperman, 2001; Tziperman and Gildor, 2003] timescales. Previous studies in Antarctica have also shown that large ice masses may only be sensitive to sea ice distributions in coastal regions [Weatherly, 2004], or that sea ice extent may respond to rather than drive continental-scale glaciation [DeConto et al., 2007].

[30] It is not clear to us what caused the expansion of cool and fresh surface water masses in the North Atlantic and Pacific Oceans during the MPT. Both Sayag et al. [2004] and DeConto et al. [2007] link the initiation of sea ice expansion at different timescales to high-latitude cooling and the development of land ice, suggesting that changes in global ice volume ought to have preceded the events recorded here. This is not our observation and alternatively, cooling of the deep waters, perhaps linked to falling atmospheric $\mathrm{CO}_{2}$ concentrations, as proposed by Tziperman and Gildor [2003] as a trigger for the sea ice switch development, would account for both the high-latitude changes observed here and the cooling observed in the upwelling systems of the tropics and subtropics. However, reconstructed deep-water temperatures for the MPT are scarce [Dwyer et al., 1995; Lear et al., 2000], as are reconstructed $p \mathrm{CO}_{2}$ values [Pearson and Palmer, 2000]. Using the deep-water data of Dwyer et al. [1995], in combination to the LR04 benthic $\delta^{18} \mathrm{O}$ stack [Lisiecki and Raymo, 2005], Clark et al. [2006] have calculated that the increasing benthic $\delta^{18} \mathrm{O}$ values across the MPT reflected a $50 \%$ ice volume increase but also a $1.4^{\circ} \mathrm{C}$ fall in deep-water temperatures. It is clear that to fully evaluate this hypothesis, high-resolution reconstructions of deep-water temperatures are required that span the MPT. However, cooling of deep waters also requires a driving mechanism, and evidence for what processes/mechanisms were behind this change must also be sought.
[31] The results presented here add to the existing evidence for global climatic change associated with the MPT, but significantly they add a missing piece to the puzzle of whether all regions of the surface ocean changed at the same time and in the same direction. The timing of the subarctic/ subpolar water mass expansion in the North Atlantic and northwest Pacific Oceans occurs alongside tropical and subtropical changes to the surface ocean and atmospheric circulation systems, including an intensification of the Trade Winds and Walker circulation systems as noted above [e.g., Durham et al., 2001; Marlow et al., 2000; McClymont and Rosell-Melé, 2005; Medina-Elizalde and Lea, 2005]. The latter have been proposed as potential triggers for Northern Hemisphere ice sheet growth [Lee and Poulsen, 2006; McClymont and Rosell-Melé, 2005]. We propose here that these impacts/links may have been moderated by the presence of expanded subarctic/subpolar water masses in the high northern latitudes. A close connection between ocean-atmosphere circulation systems between the high latitudes and the tropics is thus identified for the MPT.

\section{Conclusions}

[32] The surface ocean circulation of the North Atlantic and northwest Pacific across the MPT has been examined, using a combination of biomarker-derived proxies for water mass distributions and SSTs. A secular expansion of subarctic/subpolar water masses developed from $\sim 1.2 \mathrm{Ma}$ in both ocean basins, synchronously reaching maxima at 1.0 Ma. Modest retreat of the subpolar/subarctic water masses after $1.0 \mathrm{Ma}$ is largely driven by a more restricted interglacial distribution in the North Atlantic, as glacial maxima continue to be characterized by extensive subarctic/subpolar water masses when compared to the pre1.2 Ma climate. The resulting reduction in evaporation and equatorward deflection of the moisture-bearing westerlies would exert negative impacts on moisture transport to the boreal ice sheet source regions. We propose these impacts as a potential mechanism to account for the apparent delayed response of the Northern Hemisphere ice sheets to climate changes occurring elsewhere from 1.2 Ma. The negative feedbacks would have been most pronounced in the Atlantic, where the changing water mass distributions would have been accompanied by greater sea ice cover. The results presented here highlight the global nature of the MPT, and particularly the important implications for ice sheet growth of a coupled tropical/high-latitude ocean-atmosphere circulation system.

[33] Acknowledgments. We thank the University of Durham for a studentship to E.L.M., the Natural Environment Research Council for granting access to the Life Sciences Mass Spectrometry facility at the University of Bristol (grant NERC OMSF010), Jim Carter and Ian Bull for technical assistance with the GC-CIMS analysis at said facility, and the Spanish "Ministerio de Educación y Ciencia" for project POL200602999. We thank Marie Russell and Frank Davies for assistance in the laboratory in Durham, Stewart Jamieson for assistance with figures, the Ocean Drilling Program for providing samples, and Benjamin Flower for providing data from Site 984 . We thank Tim Herbert, two other anonymous reviewers, and James Bendle, Alfredo Martinez, Babette Hoogakker, and Alan Haywood for insightful comments and discussions. 


\section{References}

Alexander, M. A., et al. (2002), The atmospheric bridge: The influence of ENSO teleconnections on air-sea interaction over the global oceans, J. Clim., 15, 2205-2231, doi:10.1175/15200442(2002)015<2205:TABTIO > 2.0.CO;2.

Azzaroli, A. (1995), The 'Elephant-Equus' and the 'End-Villafranchian' events in Eurasia, in Paleoclimate and Evolution: With Emphasis on Human Origins, edited by E. S. Vrba et al., pp. $311-$ 318, Yale Univ. Press, New Haven, Conn.

Bard, E., et al. (1987), Retreat velocity of the North Atlantic polar front during the last deglaciation determined by ${ }^{14} \mathrm{C}$ accelerator mass spectrometry, Nature, 328, 791-794, doi:10.1038/328791a0.

Bard, E., et al. (2000), Hydrological impact of Heinrich events in the subtropical northeast Atlantic, Science, 289, 1321-1324 doi:10.1126/science.289.5483.1321.

Baumann, K.-H., and R. Huber (1999), Sea-surface gradients between the North Atlantic and the Norwegian Sea during the last $3.1 \mathrm{~m} . \mathrm{y}$ : Comparison of Sites 982 and 985, Proc. Ocean Drill. Program Sci. Results, 162, 179 - 190, doi:110.2973/odp.proc.sr.2162. 2014.1999.

Becquey, S., and R. Gersonde (2002), Past hydrographic and climate changes in the Subantarctic Zone of the South Atlantic - The Pleistocene record from ODP Site 1090, Palaeogeogr. Palaeoclimatol. Palaeoecol., 182, 221-239, doi:10.1016/S0031-0182(01) 00497-7.

Bendle, J., and A. Rosell-Melé (2004), Distributions of $U_{37}^{K}$ and $U_{37}^{K^{\prime}}$ in the surface waters and sediments of the Nordic Seas: Implications for paleoceanography, Geochem. Geophys. Geosyst., 5, Q11013, doi:10.1029/ 2004GC000741.

Bendle, J. A., A. Rosell-Melé, and P. Ziveri (2005), Variability of unusual distributions of alkenones in the surface waters of the Nordic seas, Paleoceanography, 20, PA2001, doi:10.1029/2004PA001025.

Berger, W. H., and E. Jansen (1994), MidPleistocene climate shift - The Nansen connection, in The Polar Oceans and Their Role in Shaping the Global Environment, Geophys. Monogr. Ser, vol. 84, edited by O. M. Johannessen et al., pp. 295-311, AGU, Washington, D. C

Berger, A., and M. F. Loutre (1991), Insolation values for the climate of the last 10 million years, Quat. Sci. Rev., 10, 297-317, doi:10.1016/0277-3791(91)90033-Q.

Berger, W. H., et al. (1993), Quaternary oxygen isotope record of pelagic foraminifers: Site 806, Ontong Java Plateau, Proc. Ocean Drill. Program Sci. Results, 130, 381-395.

Bertini, A. (2003), Early to middle Pleistocene changes of the Italian flora and vegetation in the light of a chronostratigraphic framework Quaternario, 16, 19-36.

Brassell, S. C., et al. (1986), Molecular stratigraphy: A new tool for climatic assessment, Nature, 320, 129-133.

Channell, J. E. T., and H. F. Kleiven (2000), Geomagnetic palaeointensities and astrochronological ages for the Matuyama-Brunhes boundary and the boundaries of the Jaramillo Subchron: Palaeomagnetic and oxygen isotope records from ODP Site 983, Philos Trans. R. Soc. London, Ser. A, 358, 10271047, doi:10.1098/rsta.2000.0572.

Clark, P. U., and D. Pollard (1998), Origin of the middle Pleistocene transition by ice sheet ero- sion of regolith, Paleoceanography, 13, 1-9, doi:10.1029/97PA02660.

Clark, P. U., et al. (2006), The middle Pleistocene transition: Characteristics, mechanisms, and implications for long-term changes in atmospheric $p \mathrm{CO}_{2}$, Quat. Sci. Rev., 25, 3150 3184, doi:10.1016/j.quascirev.2006.07.008.

Conkright, M. E., R. A. Locarnini, H. E. Garcia T. O’Brien, T. P. Boyer, C. Stephens, and J. I. Antonov (2002), Objective analyses, data statistics, and figures [CD-ROM], in World Ocean Atlas 2001, Internal Rep. 17, 17 pp. Natl. Oceanogr. Data Cent., Silver Spring, $\mathrm{Md}$.

Conte, M. H., et al. (2001), The alkenone temperature signal in western North Atlantic surface waters, Geochim. Cosmochim. Acta, 65, 4275-4287, doi:10.1016/S0016-7037(01) 00718-9.

DeConto, R., D. Pollard, and D. Harwood (2007), Sea ice feedback and Cenozoic evolution of Antarctic climate and ice sheets, $\mathrm{Pa}$ leoceanography, 22, PA3214, doi:10.1029 2006PA001350.

de Menocal, P.B. (1995), Plio-Pleistocene African climate, Science, 270, 53-59, doi:10.1126/science. 270.5233 .53 .

de Menocal, P. B. (2004), African climate change and faunal evolution during the Pliocene-Pleistocene, Earth Planet. Sci. Lett., 220 3-24, doi:10.1016/S0012-821X(04)00003-2.

Diekmann, B., and G. Kuhn (2002), Sedimentary record of the mid-Pleistocene climate transition in the southeastern South Atlantic (ODP Site 1090), Palaeogeogr. Palaeoclima tol. Palaeoecol., 182, 241-258, doi:10.1016 S0031-0182(01)00498-9.

Durham, E. L., et al. (2001), Reconstructing the climatic history of the western coast of Africa over the past 1.5 m.y.: A comparison of proxy records from the Congo Basin and the Walvis Ridge and the search for the mid-Pleistocene revolution, Proc. Ocean Drill. Program Sci. Results, 175, 1-46.

Dwyer, G. S., et al. (1995), North Atlantic Deepwater temperature change during late Pleistocene and late Quaternary climatic cycles, Science, 270, 1347-1351, doi:10.1126/ science. 270.5240 .1347 .

Endoh, T., et al. (2004), Thermohaline structure in the subarctic North Pacific simulated in a general circulation model, J. Phys. Oceanogr. 34, 360-371, doi:10.1175/1520-0485(2004) $034<0360$ :TSITSN $>2.0 . \mathrm{CO} ; 2$.

Fronval, T., and E. Jansen (1996), Late Neogene paleoclimates and paleoceanography in the Iceland-Norwegian Sea: Evidence from the Iceland and Vøring plateaus, Proc. Ocean Drill. Program Sci. Results, 151, 455-468.

Gildor, H., and E. Tziperman (2001), A sea ice climate switch mechanism for the 100-kyr glacial cycles, J. Geophys. Res., 106, $9117-$ 9133, doi:10.1029/1999JC000120.

Gröger, M., et al. (2003), Variability of silt grain size and planktonic foraminiferal preservation in Plio/Pleistocene sediments from the western equatorial Atlantic and Caribbean, Mar. Geol., $201,307-320$, doi: $10.1016 / \mathrm{S} 0025$ 3227(03)00264-0.

Hansen, B., and S. Østerhus (2000), North Atlantic-Nordic Seas exchanges, Prog. Oceanogr., 45, 109-208, doi:10.1016/S0079. 6611(99)00052-X

Harada, N., et al. (2006), Characteristics of alkenone distributions in suspended and sinking particles in the northwestern North Pacific,
Geochim. Cosmochim. Acta, 70, 2045-2062, doi:10.1016/j.gca.2006.01.024

Haug, G. H. (1996), Paleoceanography and sedimentation history in the Northwest Pacific during the last 6 Mio years (ODP Site 882), Ph.D. thesis, 142 pp., Geol.-Paläontol. Inst. und Mus., Christian-Albrechts-Univ., Kiel, Germany.

Haug, G. H., et al. (1995), Evolution of northwest Pacific sedimentation patterns since $6 \mathrm{Ma}$ (Site 882), Proc. Ocean Drill. Program Sci. Results, 145, 293-314.

Haug, G. H., et al. (1999), Onset of permanent stratification in the subarctic Pacific Ocean, Nature, 401, 779-782, doi:10.1038/44550.

Haug, G. H., et al. (2005), North Pacific seasonality and the glaciation of North America 2.7 million years ago, Nature, 433, $821-$ 825, doi: 10.1038 /nature 03332

Head, M. J., , and P. L. Gibbard (Eds.) (2005), Early middle Pleistocene transitions: The land-ocean evidence, Geol. Soc. Spec. Publ., $247,1-262$

Helmke, J. P., et al. (2003a), Development of glacial and interglacial conditions in the Nordic seas between 1.5 and $0.35 \mathrm{Ma}$, Quat. Sci. Rev., 22, 1717-1728, doi:10.1016/S02773791(03)00126-4

Helmke, J. P., et al. (2003b), Evidence for a midPleistocene shift of ice-drift pattern in the Nordic Seas, J. Quat. Sci., 18, 183-191, doi:10.1002/jqs.735.

Henrich, R., and K.-H. Baumann (1994), Evolution of the Norwegian Current and the Scandinavian ice sheets during the past $2.6 \mathrm{~m}$.y. Evidence from ODP Leg 104 biogenic carbonate and terrigenous records, Palaeogeogr. Palaeoclimatol. Palaeoecol., 108, 75-94 doi:10.1016/0031-0182(94)90023-X.

Henrich, R., et al. (2002), Carbonate preservation records of the past $3 \mathrm{Myr}$ in the Norwegian-Greenland Sea and the northern North Atlantic: Implications for the history of NADW production, Mar. Geol., 184, 17-39, doi:10.1016/S0025-3227(01)00279-1.

Heslop, D., et al. (2002), Timing and structure of the mid-Pleistocene transition: Records from the loess deposits of northern China, Palaeogeogr. Palaeoclimatol. Palaeoecol., 185, $133-$ 143, doi:10.1016/S0031-0182(02)00282-1.

Imbrie, J., et al. (1993), On the structure and origin of major glacial cycles 2. The 100,000-year cycle, Paleoceanography, 8 , 699-736, doi:10.1029/93PA02751.

Jaccard, S. L., et al. (2005), Glacial/interglacial changes in subarctic North Pacific stratification, Science, 308, 1003-1006, doi:10.1126/science. 1108696.

Jansen, E., et al. (1996), Site 983, Proc. Ocean Drill. Program Initial Rep., 162, 139-167.

Kawagata, S., et al. (2005), Mid-Pleistocene extinction of deep-sea foraminifera in the North Atlantic Gateway (ODP Sites 980 and 982), Palaeogeogr. Palaeoclimatol. Palaeoecol., 221, 267-291, doi:10.1016/j.palaeo.2005 03.001

Kleiven, H. F., E. Jansen, W. B. Curry, D. A. Hodell, and K. Venz (2003), Atlantic Ocean thermohaline circulation changes on orbital to suborbital timescales during the mid-Pleistocene, Paleoceanography, 18(1), 1008, doi:10.1029/ 2001PA000629.

Koç, N., et al. (1999), High-resolution Pleistocene diatom stratigraphy of Site 983 and correlations with isotope stratigraphy, Proc. Ocean Drill. Program Sci. Results, 162, 51-62. 
Koster, R. D., J. Jouzel, R. Suozzo, G. Russell, W. Broecker, D. Rind, and P. Eagleson (1986), Global sources of local precipitation as determined by the NASA/GISS GCM, Geophys. Res. Lett., 13, 121-124, doi:10.1029/ GL013i002p00121.

Lear, C. H., et al. (2000), Cenozoic deep-sea temperatures and global ice volumes from $\mathrm{Mg} / \mathrm{Ca}$ in benthic foraminiferal calcite, Science, 287, 269-272, doi:10.1126/ science.287.5451.269.

Lee, S.-Y., and C. J. Poulsen (2006), Sea ice control of Plio-Pleistocene tropical Pacific climate evolution, Earth Planet. Sci. Lett., 248, 238-247, doi:10.1016/j.epsl.2006.05.030.

Lisiecki, L. E., and M. E. Raymo (2005), A Pliocene-Pleistocene stack of 57 globally distributed benthic $\delta^{18} \mathrm{O}$ records, Paleoceanography, 20, PA1003, doi:10.1029/ 2004PA001071.

Liu, Z., and T. D. Herbert (2004), High-latitude influence on the eastern equatorial Pacific climate in the early Pleistocene epoch, Nature, 427, 720 - 723, doi: 10.1038 /nature 02338 .

Marlow, J. R., et al. (2000), Upwelling intensification as part of the Pliocene-Pleistocene climate transition, Science, 290, 2288-2291.

Marlowe, I. T., et al. (1990), Long-chain alkenones and alkyl alkenoates and the fossil coccolith record of marine sediments, Chem. Geol., 88, 349-375, doi:10.1016/00092541(90)90098-R.

McClymont, E. L., and A. Rosell-Melé (2005), Links between the onset of modern Walker Circulation and the mid-Pleistocene climate transition, Geology, 33, 389-392, doi:10.1130/ G21292.1.

McClymont, E. L., et al. (2005), Alkenone and coccolith records of the mid-Pleistocene in the south-east Atlantic: Implications for the $\mathrm{U}_{37}^{\mathrm{K}^{\prime}}$ index and South African climate, Quat. Sci. Rev., 24, 1559-1572, doi:10.1016 j.quascirev.2004.06.024

McManus, J. F., et al. (2002), Thermohaline circulation and prolonged interglacial warmth in the North Atlantic, Quat. Res., 58, 17-21, doi:10.1006/qres.2002.2367.

Medina-Elizalde, M., and D. W. Lea (2005), The Mid-Pleistocene transition in the tropical $\mathrm{Pa}$ cific, Science, 310, 1009-1012, doi:10.1126/ science. 1115933 .

Meggers, H., and K.-H. Baumann (1997), Late Pliocene/Pleistocene calcareous plankton and paleoceanography of the North Atlantic, in Contributions to the Micropaleontology and $\mathrm{Pa}$ leoceanography of the Northern North Atlantic, edited by H. C. Hass and M. A. Kaminski, Spec. Publ. 5, pp. 39-50, Grzybowski Found., Cracow.

Mudelsee, M., and M. Schulz (1997), The MidPleistocene climate transition: Onset of $100 \mathrm{ka}$ cycle lags ice volume build-up by $280 \mathrm{ka}$, Earth Planet. Sci. Lett., 151, 117-123, doi:10.1016/S0012-821X(97)00114-3.

Müller, P. J., et al. (1998), Calibration of the alkenone paleotemperature index $\mathrm{U}_{37}^{\mathrm{K}^{\prime}}$ based on core-tops from the eastern South Atlantic and the global ocean $\left(60^{\circ} \mathrm{N}-60^{\circ} \mathrm{S}\right)$, Geochim. Cosmochim. Acta, 62, 1757-1772, doi:10.1016/S0016-7037(98)00097-0.

O’Neill, T. A., et al. (2007), Pleistocene extinctions of deep-sea benthic foraminifera: The South Atlantic record, Palaeontology, 50, 1073-1102, doi:10.1111/j.1475-4983. 2007.00702.x

Opdyke, N. D. (1995), Mammalian migration and climate over the last seven million years, in Paleoclimate and Evolution: With Emphasis on Human Origins, edited by E. S. Vrba et al., pp. 109-114, Yale Univ. Press, New Haven, Conn.

Oppo, D. W., M. E. Raymo, G. P. Lohmann, A. C. Mix, J. D. Wright, and W. L. Prell (1995), A $\delta^{13} \mathrm{C}$ record of Upper North Atlantic Deep Water during the past 2.6 million years, Paleoceanography, 10, 373-394, doi:10.1029/95PA00332.

Pearson, P. N., and M. R. Palmer (2000), Atmospheric carbon dioxide concentrations over the past 60 million years, Nature, 406, 695-699, doi: $10.1038 / 35021000$.

Pflaumann, U., et al. (2003), Glacial North Atlantic: Sea-surface conditions reconstructed by GLAMAP 2000, Paleoceanography, 18(3), 1065, doi:10.1029/2002PA000774.

Prahl, F. G., and S. G. Wakeham (1987), Calibration of unsaturation patterns in long-chain ketone compositions for palaeotemperature assessment, Nature, 330, 367-369, doi:10.1038/ $330367 \mathrm{a} 0$.

Prahl, F. G., et al. (1988), Further evaluation of long-chain alkenones as indicators of paleoceanographic conditions, Geochim. Cosmochim. Acta, 52, 2303-2310, doi:10.1016/ 0016-7037(88)90132-9.

Raymo, M. E., and K. Niscancioglu (2003), The 41 kyr world: Milankovitch's other unsolved mystery, Paleoceanography, 18(1), 1011, doi:10.1029/2002PA000791.

Raymo, M. E., et al. (1990), Evolution of Atlantic-Pacific $\delta^{13} \mathrm{C}$ gradients over the last $2.5 \mathrm{~m}$.y, Earth Planet. Sci. Lett., 97, 353-368, doi:10.1016/0012-821X(90)90051-X.

Raymo, M. E., D. W. Oppo, B. P. Flower, D. A Hodell, J. F. McManus, K. A. Venz, K. F. Kleiven, and K. McIntyre (2004), Stability of North Atlantic water masses in face of pronounced climate variability during the Pleistocene, Paleoceanography, 19, PA2008, doi:10.1029/2003PA000921.

Rea, D. K., et al. (1993), Proceedings of the Ocean Drilling Program, Initial Reports, vol. 145, Ocean Drill. Program, College Station, Tex

Rosell-Melé, A. (1998), Interhemispheric appraisal of the value of alkenone indices as temperature and salinity proxies in high-latitude locations, Paleoceanography, 13, 694-703, doi:10.1029/98PA02355.

Rosell-Melé, A., et al. (1994), Distributions of long-chain alkenones and alkyl alkenoates in marine surface sediments from the North East Atlantic, Org. Geochem., 22, 501-509, doi:10.1016/0146-6380(94)90122-8.

Rosell-Melé, A., et al. (1995a), Determination of the $\mathrm{U}_{37}^{\mathrm{K}}$ index in geological samples, Anal. Chem., 67, 1283-1289, doi:10.1021/ ac00103a021.

Rosell-Melé, A., et al. (1995b), Atlantic core-top calibration of the $U_{37}^{K}$ index as a sea-surface palaeotemperature indicator, Geochim. Cosmochim. Acta, 59, 3099-3107, doi:10.1016/ 0016-7037(95)00199-A

Rosell-Melé, A., et al. (1998), Variability of the Arctic front during the last climatic cycle: Application of a novel molecular proxy, Terra Nova, 10, 86-89, doi:10.1046/j.1365 3121.1998.00172.x

Rosell-Melé, A., et al. (2002), Appraisal of a molecular approach to infer variations in surface ocean freshwater inputs into the North Atlantic during the last glacial, Global Planet. Change, 34, 143-152, doi:10.1016/S09218181(02)00111-X.

Ruddiman, W. F., and A. McIntyre (1979), Warmth of the subpolar North Atlantic Ocean during Northern Hemisphere ice-sheet growth Science, 204, 173-175, doi:10.1126/ science.204.4389.173.

Ruddiman, W. F., et al. (1980), Ocean evidence for the mechanism of rapid Northern Hemisphere glaciation, Quat. Res., 13, 33-64, doi:10.1016/0033-5894(80)90081-2.

Ruddiman, W. F., et al. (1986), Paleoenvironmental results from North Atlantic Sites 607 and 609, Deep Sea Drill. Program Initial Rep., 94, 855-878.

Sancetta, C., and S. Silvestri (1986), PliocenePleistocene evolution of the North Pacific ocean-atmosphere system, interpreted from fossil diatoms, Paleoceanography, 1, 163180, doi:10.1029/PA001i002p00163.

Sayag, R., E. Tziperman, and M. Ghil (2004), Rapid switch-like sea ice growth and land ice-sea ice hysteresis, Paleoceanography, 19, PA1021, doi:10.1029/2003PA000946.

Schefuß, E., et al. (2003), African vegetation controlled by tropical sea surface temperatures in the mid-Pleistocene period, Nature, 422, 416-421.

Schmieder, F., et al. (2000), The Mid-Pleistocene climate transition as documented in the deep South Atlantic Ocean: Initiation, interim state, and terminal event, Earth Planet. Sci. Lett., 179, 539-549, doi:10.1016/S0012-821X(00) 00143-6

Sejrup, H. P., et al. (2000), Quaternary glaciations in southern Fennoscandia: Evidence from southwestern Norway and the northern North Sea region, Quat. Sci. Rev., 19, $667-$ 685, doi:10.1016/S0277-3791(99)00016-5.

Sicre, M. A., et al. (2002), Alkenone distributions in the North Atlantic and Nordic sea surface waters, Geochem. Geophys. Geosyst., 3(2), 1013, doi:10.1029/2001GC000159.

Sikes, N. E. (1999), Plio-Pleistocene floral context and habitat preferences of sympatric hominid species in East Africa, in African Biogeography, Climate Change, and Human Evolution, edited by T. G. Bromage and F. Schrenk, pp. 301-315, Oxford Univ. Press, New York.

Smith, L. M., et al. (2003), Sensitivity of the Northern Hemisphere climate system to extreme changes in Holocene Arctic sea-ice, Ouat. Sci. Rev., 22, 645-658, doi:10.1016/ S0277-3791(02)00166-X.

St. John, K. E. K., and L. A. Krissek (1999), Regional patterns of Pleistocene ice-rafted debris flux in the North Pacific, Paleoceanography, 14,653-662, doi:10.1029 1999PA900030

Swift, J. (1986), The Arctic waters, in The Nordic Seas, edited by B. G. Hurdle, pp. 129-151, Springer, New York.

Tabata, S. (1975), The general circulation of the Pacific Ocean and a brief account of the oceanographic structure of the North Pacific Ocean. Part I, circulation and volume transports, Atmosphere, 13, 134-168.

Thierstein, H. R., et al. (1977), Global synchroneity of late Quaternary coccolith datum levels: Validation by oxygen isotopes, Geology, 5, $400-404$, doi:10.1130/0091-7613(1977) $5<400$ :GSOLOC $>2.0 . \mathrm{CO} ; 2$

Tiedemann, R., and G. H. Haug (1995), Astronomical calibration of cycle stratigraphy for Site 882 in the northwest Pacific, Proc. Ocean Drill. Program Sci. Res., 145, 283-292.

Tziperman, E., and H. Gildor (2003), On the mid-Pleistocene transition to $100-\mathrm{ky}$ glacial cycles and the asymmetry between glaciation and deglaciation times, Paleoceanography, 18(1), 1001, doi:10.1029/2001PA000627. 
Wang, H., and I. N. McCave (1990), Distinguishing climatic and current effects in midPleistocene sediments of Hatton and Gardar Drifts, NE Atlantic, J. Geol. Soc., 147, $373-$ 383, doi:10.1144/gsigs.147.2.0373.

Weatherly, J. W. (2004), Sensitivity of Antarctic precipitation to sea ice concentrations in a general circulation model, J. Clim., 17 3214-3223, doi:10.1175/1520-0442(2004) 017<3214:SOAPTS $>2.0 . C O ; 2$.

Wright, A. K., and B. P. Flower (2002), Surface and deep ocean circulation in the subpolar
North Atlantic during the mid-Pleistocene revolution, Paleoceanography, 17(4), 1068, doi:10.1029/2002PA000782.

Xiao, J., and Z. An (1999), Three large shifts in East Asian monsoon circulation indicated by loess-paleosol sequences in China and late Cenozoic deposits in Japan, Palaeogeogr. $\mathrm{Pa}$ laeoclimatol. Palaeoecol., 154, 179-189, doi:10.1016/S0031-0182(99)00110-8.

Yuan, X., and L. D. Talley (1996), The subarctic frontal zone in the North Pacific: Characteristics of frontal structure from climatological data and synoptic surveys, $J$. Geophys. Res. $101,16,491-416,508$

G. H. Haug, Geological Institute, Department of Earth Sciences, ETH Zürich, Universitätsstrasse 22, CH-8092 Zürich, Switzerland.

J. M. Lloyd, Department of Geography, University of Durham, Durham DH1 3LE, UK.

E. L. McClymont, School of Geography, Politics, and Sociology, Newcastle University, Newcastle upon Tyne NE1 7RU, UK. (erin.mcclymont@ncl.ac.uk)

A. Rosell-Melé, Institut de Ciència i Tecnologia Ambientals, Universitat Autònoma de Barcelona, E-08193 Bellaterra, Catalonia, Spain. 